American Journal of Environmental Sciences 7 (5): 477-491, 2011

ISSN 1553-345X

(C) 2011 Science Publications

\title{
Sequential Remediation Processes for Effective Removal of Oil from Contaminated Soils
}

\author{
Deepika Dave, Reema Alharathi and Abdel Ghaly \\ Department of Process Engineering and Applied Science, \\ Faculty of Engineering, Dalhousie University, Halifax, Nova Scotia, Canada
}

\begin{abstract}
Problem statement: Over 2.2 billions of oil and oil products were transported every year and often these activities can result in air, water and soil contamination. Expousure to petroleum products can cause health problems to humn and animals and affect marine animals and wildlife habitats. Approach: The objective of this study was to developed a technology for the remediation of soil contaminated with petroleum hydrocarbons. The remediation method included three processes: (a) an effective soil washing process for the removal of the hydrocarbons from the contaminated soil, (b) an efficient water decontamination process using peat moss as an oil absorbent and (c) an effective bioremediation process for converting the oil in peat moss into carbon dioxide and water. Results: The results showed that water was an effective solvent for the removal of oil from contaminated soil. It had also been determined that peat moss is an effective absorbent and could be used to remove oil from the contaminated water. Peat can absorb 12.6 times its weight liquid (water/oil). The bioremediation process was effective in degrading the oil into harmless carbon dioxide and water products. About $77.65 \%$ of the THC was removed within 60 days of bioremediation. The hemophilic microbial population in the compost quickly acclimatized to the hydrocarbon as was evident from the immediate rise in the reactor temperature. The $\mathrm{C}$ : $\mathrm{N}$ ratio decreased from 30:1-12:1 indicating the degradation of organic $\mathrm{C}$ in the petroleum hydrocarbons and the peat. Urea was a very effective source of nitrogen in initiating and maintaining intense microbial respiration activity. Conclusion: A sequential processes for the remediation of oil contaminated soil is developed. These included soil washing, absorption of oil from water using peat and bioremediation of contaminated peat. A degradation model is developed and used to calculate the time required for a complete degradation. The model indicated that a total degradation of oil could be achieved within 68.5 days.
\end{abstract}

Key words: Oil contaminated soil, peat moss, washing filtration, bioremediation urea, compost, temperature, moisture content, effective source, total degradation

\section{INTRODUCTION}

Oil accounts for approximately $35 \%$ of total global energy usage and consists of several hydrocarbons BP, 2010. They are a family of compounds that are composed essentially of carbon and hydrogen; some may contain oxygen and traces of other elements (Metman et al., 2010). Petroleum hydrocarbons serve as fuels and lubricants as well as raw materials for the production of plastics, rubbers, explosives, fibers, solvents and industrial chemicals. Over 2.2 billion tons of oil and oil products are transported each year and often activities such as export, local transport and general uses can result in severe air, water and soil pollution. Oil contamination can results from: (a) leakage from under or above ground storage tanks, (b) improper disposal of waste lubricating oils, (c) accidental release from oil handling facilities and (d) marine accidents. These contaminants threaten human and animal health and affects waterfowl, fisheries, marine food webs, marine animals and wildlife habitats (Fingas, 1994; Lee and Page, 1997; Toyoda and Inagaki 2000; Alonso-Alvarez et al., 2007; Chen et al., 2010). Human exposure to low concentrations of petroleum products can result in headaches, skin irritations, itchy eyes or burning sensations in internal organs. If exposure is prolonged and the concentration of the oil is high, liver or kidney disease may develop, bone marrow damage is possible and the risk of cancer is increased (Baars, 2002; Rodriguez-Trigo et al., 2007).

Corresponding Author: Abdel Ghaly, Department of Process Engineering and Applied Science, Faculty of Engineering, Dalhousie University, Halifax, Nova Scotia, Canada. Tel: (902) 494-6014; 
Am. J. Environ. Sci., 7 (5): 477-491, 2011

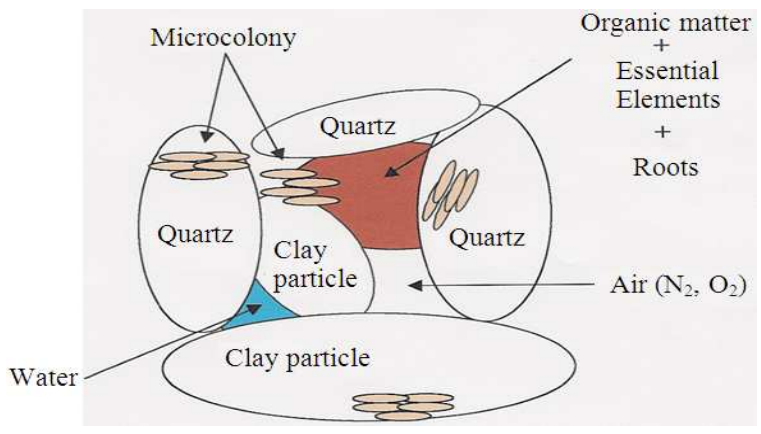

Fig. 1: Major components of soil

Many marine animals depend on their feathers or fur for warmth and when they become coated with oil their water-repellent shields are worn down and they risk freezing to death. Oil clogs the nose and irritates the eyes of birds and may be directly ingested into their systems leading to stomach ulceration and bleeding (Baars, 2002). These environmental and health problem can negatively impact the economy.

Soil remediation techniques can be performed in situ or ex situ and can be thermal, physical, biological or chemical in nature (Riser-Roberts, 1992; Arnold and Anderson, 2002; Pavel and Gavrilescu, 2008). Thermal remediation techniques include incineration, thermal desorption and radio frequency heating. These processes utilize heat to degrade organic contaminants, are expensive and can cause air pollution and irreversible soil degradation (Roland et al., 2008; Dermatas and Meng, 2003). Physical remediation techniques include soil washing and landfilling which simply transfer the problem from one area to another (Chu and Chan, 2003; Rushton et al., 2007). Chemical addition is another method of soil remediation in which chemicals are added to the soil to oxidize the foreign organic contaminants and in some cases may require excavation of the contaminated soils and transporting them to a treatment site. They are expensive, create dust and may release contaminants into the atmosphere (Sherwood and Qualls, 2001; Suthersan, 1997). Biological methods include bioremediation, landfarming, biopiling, composting, bioventing and liquid delivery systems (Riser-Roberts, 1992; Mihopoulos et al., 2002). These methods utilize natural degradation properties and can often take a lot of time and space (Rushton et al., 2007).

Bioremediation is the use of microorganisms to breakdown environmental pollutants in soil and water (Maier et al., 2000). Bioremediation is becoming more common to clean up oil spills on land (Ghaly et al., 1999; Ghaly et al., 2007). In nature, biodegradation is a very slow process, so it is important to provide nutrients and to optimize the environmental conditions for the microorganisms (Ghaly et al., 2007). In bioremediation, oil is metabolized by microorganisms and broken down into water, carbon dioxide and other inorganic chemicals (Atlas, 1995). All microbes need nitrogen, phosphorous, carbon and traces of sulfur, potassium, calcium, magnesium, iron, boron, manganese, zinc, molybdenum, copper and chlorine (Alexander, 1999; Waites, 2001). Environmental parameters such as $\mathrm{O}_{2}$, water, $\mathrm{pH}$, temperature and substrate concentration affect microbial growth and the rate of biodegradation. Oxygen is needed for cellular metabolism and water is needed for transportation of elements across the membrane (Alexander, 1999). $\mathrm{pH}$ and temperature can greatly impact microbial growth and higher the concentration of the matter being biodegraded may also affect the process of biodegradation and even inhibit their growth (Filler et al., 2008).

Generally, natural soil is made up of 5 major components (Fig. 1): minerals, air, water, living organisms and organic materials (Ghaly et al., 1999). The organic component (3-6\%) is made of the remains of plants and animals and the products of their decomposition. The inorganic component (over 50\%) is the products of the rocks that have been broken down by chemical actions and natural processes and includes mostly Silicon dioxide $\left(\mathrm{SiO}_{2}\right)$, aluminum and iron. Calcium, magnesium, potassium, titanium, manganese, sodium, nitrogen, phosphorus and sculpture are present in lesser quantities. Air and water take up $25-50 \%$ of the total volume of soil and the specific percentage wavers dramatically with the moisture content of soil and the soil type (Astera, 2010). The living organisms (less than 1\%) are the primary decomposers (biodegrades) of dead materials. A gram of soil may contain up to a billion bacteria, a million algae, 100 thousand protozoa and $10 \mathrm{~km}$ of fungi hyphae (Trevors, 2010). Table 1 shows a list of known hydrocarbons degrading microorganisms (Beilen et al., 2003; Wentzel et al., 2007; Kubota et al., 2008; Prince1 et al, 2003; Capotorti et al., 2004).

Peat moss also known as Bog Moss and Sphagnum Moss and can absorb contaminates found in water and the atmosphere. Peat moss is any of more than 300 species of plants of the order Sphagnales, made up from the family Sphagnaceae, which contains the only genus, Sphagnum (Scott, 1996). It is a plant matter that is partially fossilized and is built up by partial decay and carbonization of vegetation in the acid water of bogs. The peat moss plant can hold up to 20 times its weight in water (Barrington and Moreno, 1995). Peat moss is found in bogs throughout Canada, Siberia and northern. Europe (Cullina, 2008). Canada produces about $1.4 \times 106$ tons annually which are exported to Japan, USA, Holland, Germany, England and Saudi Arabia (Mitsch and Gosselink, 2007). 
Am. J. Environ. Sci., 7 (5): 477-491, 2011

Table 1: Known hydrocarbons degrading microorganisms (Beilen et al., 2003; Wentzel et al., 2007; Kubota et al., 2008; Prince1 et al., 2003; Capotorti et al., 2004)

\begin{tabular}{|c|c|c|}
\hline Category & Compound & Micro-Organisms \\
\hline \multirow[t]{4}{*}{ Straight chain alkanes } & Methane & $\begin{array}{l}\text { Psedomonas methanica, Myobacterium } \\
\text { fortuitum, Mycobacterium smegmatis }\end{array}$ \\
\hline & Ethane & Pseudomonas methanica \\
\hline & Propane & Pseudobacterium sublteum \\
\hline & Butane & Pseudomonas fluorescens, Actinomyces candidus, Corynebacterium \\
\hline Branched alkanes & Isobutane & Corynebacterium, Brevibacterium erythrogenes \\
\hline Cyclic alkanes & Cyclopropane & Nocardia $\mathrm{sp}$, Xanthobacter $\mathrm{sp}$ \\
\hline Alkenes & Ethylene & Candida lipolytica, Pseudomonas oleovorans \\
\hline \multirow[t]{9}{*}{ Aromatics } & Phenol & $\begin{array}{l}\text { Pseudomonas putida, Acinetobacte r calcoaticus, Vibrio sp., Spirillum sp., } \\
\text { Bacillus sp., Norcardia } \mathrm{sp} ., \text { Chromobacter } \mathrm{sp} ., \text { Flavobacterium } \mathrm{sp} .\end{array}$ \\
\hline & Benzene & Pseudomonas sp., Acinetobacter sp., Nocardia sp. \\
\hline & Ethylbenzene & Nocardia sp., Acinetobacter sp. \\
\hline & Toluene & $\begin{array}{l}\text { Pseudomonas sp., Achromobacter sp., } \\
\text { Pseduomonas aeruginosa, Micrococcus, Acinetobacter sp. }\end{array}$ \\
\hline & Xylenes & Pseudomonas putida, Nocardia sp. \\
\hline & Napthalene & Nocardia sp. Nostoc sp., Cunninghanella elegans, Coccochloris sp. \\
\hline & Anthracene, Pyrene & Achromobacter sp., Beijerinckia sp. \\
\hline & Benzo(a)anthracene & Cunninghanella elegans, Beijerinckia sp. \\
\hline & Benzo(a)pyrene & Beijerinckia sp., Candida lipolytica \\
\hline
\end{tabular}

Objectives: The object of this study was to develop a system for the remediation of soil contaminated with petroleum hydrocarbons. The specific objectives were: (a) to develop an effective soil washing process for the removal of the hydrocarbons from the contaminated soil, (b) to develop an efficient water decontamination process using peat moss and (c) to evaluate the effectiveness of bioremediation in converting the oil in peat moss into carbon dioxide and water.

\section{MATERIALS AND METHODS}

Diesel fuel: The diesel fuel used in this experiment was Number 1 Grade A (10W 30) usually used in engines that have frequent load and speed changes. A $10 \mathrm{~L}$ sample was obtained in a certified high-density polyethylene plastic fuel container from an Oil Retail Outlet in Halifax, Nova Scotia. Some characteristics the oil used in the study are shown in Table 2.

Soil: The soil used in this experiment was Stewiacke Series, obtained from a corn field in Truro, Nova Scotia. The soil was classified as imperfectly drained sandy loam with medium texture and a particle size distribution of 21 clay, 20 silt and 59\% sand. It has a slow permeability of $0.036 \mathrm{~m} \mathrm{~h}^{-1}$, a pH of 5.8 and a bulk density of $1400 \mathrm{~kg} \mathrm{~m}^{-3}$. Some characteristics of the soil used in this study are shown in Table 2 .

Peat moss: A $9 \mathrm{~kg}$ sample of Cansorb Organic Oil Absorbent type peat, manufactured by AVP Cansorb, Berwick, Nova Scotia, was collected for this experiment. The sample was obtained from the manufacturer in a sealed plastic bag. Some characteristics of the peat used in the study are shown in Table 2 .

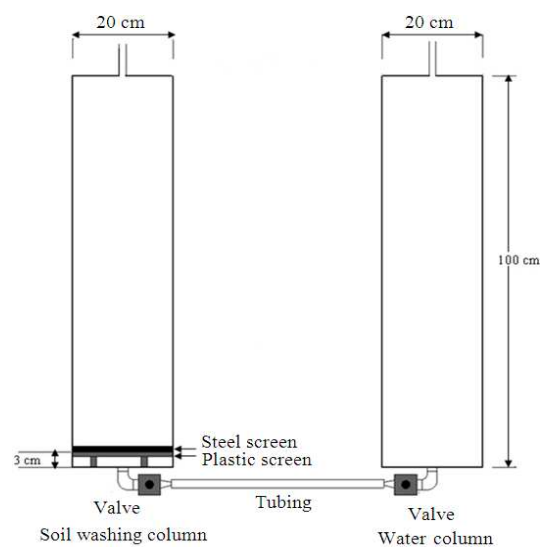

Fig. 2: Soil washing system

Compost: A15-day old municipal solid compost was obtained from a composting facility operated by Miller Composting Corporation, Dartmouth, Nova Scotia. Some characteristics of the compost are shown in Table 2.

Urea: Urea [CO $\left.\left(\mathrm{NH}_{2}\right)_{2}\right]$ was purchased from Halifax Seed Company in Halifax, Nova Scotia. It was added as a nitrogen source to adjust the C:N ratio to $30: 1$. The choice of urea was based on the study by Ghaly and Pyke (2001), Alkoaik and Ghaly (2006a) and Ghaly et al. (2007) which indicated that urea was an effective source of nitrogen in initiating and maintaining intense microbial respiration activity. Some characteristics of the urea are shown in Table 2.

Soil washing system: The soil washing system Fig. 2 consists of two Plexiglas columns $(20 \mathrm{~cm}$ diameter, 100 $\mathrm{cm}$ height and $0.7 \mathrm{~cm}$ wall thickness), each resting on a wooden support. One column had water while the other had the oil-contaminated soil. 
Am. J. Environ. Sci., 7 (5): 477-491, 2011

Table 2: Some characteristics ${ }^{+}$of materials used in this study

\begin{tabular}{|c|c|c|c|c|c|}
\hline \multirow[b]{2}{*}{ Characteristic } & \multicolumn{5}{|l|}{ Value } \\
\hline & Oil $^{*}$ & Soil & Peat & Compost & Urea \\
\hline Bulk density $\left(\mathrm{kg} / \mathrm{m}^{3}\right)$ & 892.000 & 1400.00 & 1500.0 & 912.0 & \\
\hline Moisture content (\%) & 0.000 & 20.00 & 8.0 & 58.6 & \\
\hline \multicolumn{6}{|l|}{ Total solids (mg/g DM) } \\
\hline Volatile solids $* *$ & 999.45 & 264.00 & 977.4 & 854.6 & \\
\hline Ash & 0.55 & 736.00 & 22.6 & 45.4 & \\
\hline \multicolumn{6}{|l|}{ Nitrogen (mg/g DM) } \\
\hline Total kjeldahl nitrogen & 0.22 & 2.00 & 2.0 & 18.0 & 466.6 \\
\hline Ammonium nitrogen & & 0.120 & 0.2 & 5.2 & \\
\hline \multicolumn{6}{|l|}{ Carbon $(\mathrm{mg} / \mathrm{g}$ DM) } \\
\hline Total & 854.00 & 99.00 & 490.0 & 440.0 & 200.0 \\
\hline Organic & 854.00 & 55.00 & 390.0 & 350.0 & 200.0 \\
\hline \multicolumn{6}{|c|}{ Elemental composition (mg/g DM) } \\
\hline $\mathrm{B}$ & & & & & 0.2 \\
\hline $\mathrm{Ca}$ & 0.06 & 0.10 & 0.8 & 20.0 & \\
\hline $\mathrm{Cu}$ & & & & & 0.7 \\
\hline $\mathrm{Na}$ & 0.30 & 0.20 & 0.2 & 6.2 & \\
\hline $\mathrm{Fe}$ & 0.14 & 0.90 & 0.3 & 2.8 & 1.2 \\
\hline $\mathrm{Mg}$ & 0.01 & 0.70 & 0.4 & 1.8 & 0.5 \\
\hline $\mathrm{Zn}$ & 0.00 & 0.20 & 0.3 & 0.1 & 0.3 \\
\hline K & 0.01 & 0.20 & 0.6 & 7.8 & \\
\hline $\mathrm{Cl}$ & 0.74 & 0.10 & 0.3 & 0.3 & \\
\hline $\mathrm{P}$ & 0.01 & 0.90 & 0.9 & 2.7 & \\
\hline S & 2.32 & 2.90 & 0.9 & 2.3 & \\
\hline Others $* *$ & 0.16 & 724.80 & 17.9 & 101.4 & \\
\hline $\mathrm{C}: \mathrm{N}$ & $3272: 1$ & $47: 1$ & $223: 1$ & $19: 1$ & \\
\hline
\end{tabular}

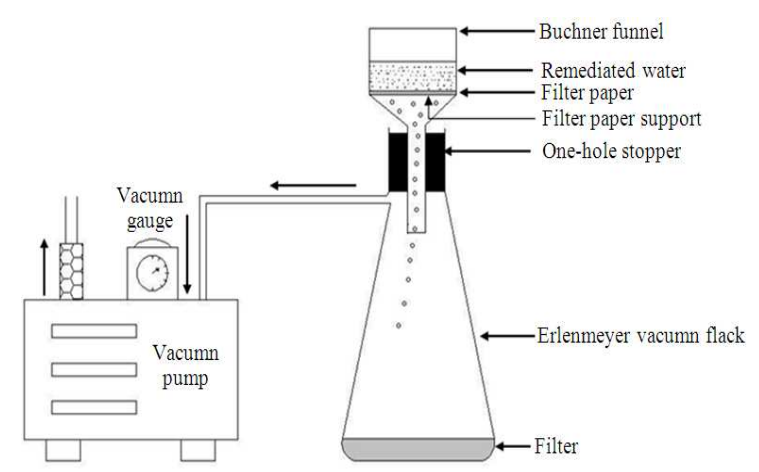

Fig. 3: Filtration system

The bottom and cover of each column were made of 7 $\mathrm{mm}$ thick Plexiglas circular plates of $20 \mathrm{~cm}$ diameter. The bottom plate was glued to the cylinder whereas the cover was secured into the column using six stainless steel screws and wing nuts. The cover had a $15 \mathrm{~mm}$ diameter hole in the center to release air. An outlet port was provided at the center of the bottom of each column which was fitted with $19 \mathrm{~mm}$ (OD) PVC elbow.
A $60 \mathrm{~cm}$ tygon tube attached the two cylinders, with a valve (Chemline, 15-1/2 Type 83 C-ball valve) on each end of the tube to start and stop the flow of water from the water column to the soil column. A $5 \mathrm{~mm}$ thick circular plastic screen (mesh number 4) was positioned at the bottom of the soil column above 4 legs of $6 \mathrm{~mm}$ height which allowed the circulation of water through the soil. A stainless steel screen (mesh number 18) was placed above the screen to prevent soil particles from plugging the tube.

Filtration system: The water filtration system Fig. 3 consisted of a large capacity PVC Buchner filtration funnel (Model No 420-1500, Nalge, Syborn International, New York, USA) placed on a 2 L Erlenmeyer vacuum flask (No. 5340-2L Pyrex, New York, USA) which was connected to a vacumn pump (Model No. 5- High Purity, Edward Pumps, Sussex, New York, USA). A $15 \mathrm{~cm}$ diameter filter paper (No. 41, Whatman International Ltd., Maidstone, England) was placed in the filtration funnel to capture the peat moss. 


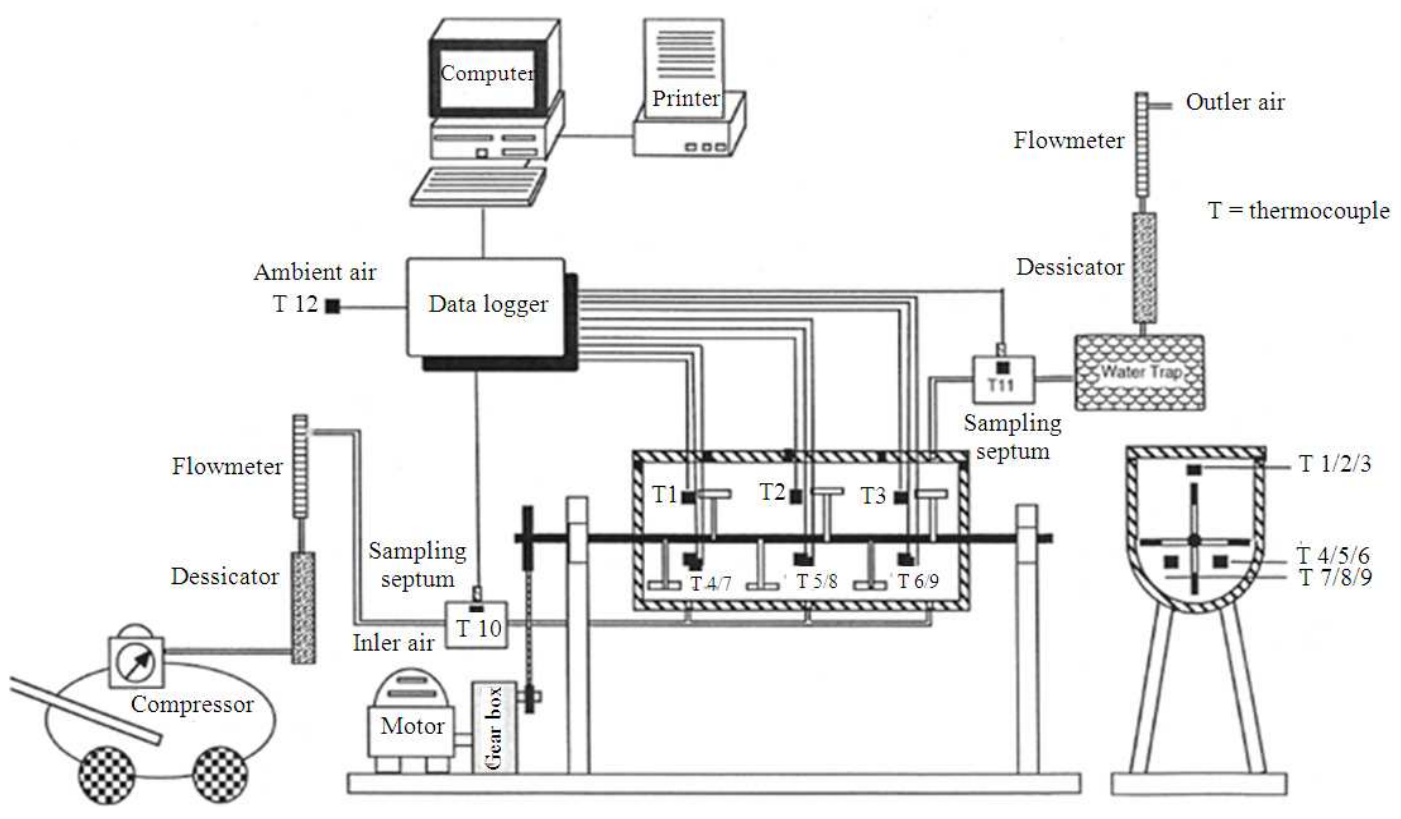

Fig. 4: Bioremediation system

Bioremediation system: The bioremediation system Fig. 4 consisted of a bioreactor, a mixing unit, an aeration unit and a temperature measurement unit. The bioreactor was made of $6.4 \mathrm{~mm}$ thick stainless steel. The sides of the vessel measured $340 \times 280 \mathrm{~mm}$ and had a radius of $150 \mathrm{~mm}$ at the lower end. The top of the vessel $(340 \times 800 \mathrm{~mm})$ was held in place by four hinges placed on one side which allowed for the closing and opening of the top of the vessel. Four locking clamps were provided on the other side to ensure adequate sealing and easy locking of the top cover when the bioreactor was in operation. A rubber gasket lining was used to prevent air leakage from the bioreactor during the process. The top cover and walls of the bioreactor were insulated with $25.4 \mathrm{~mm}$ thick Styrofoam layer. There were three holes at the bottom of the vessel, which were connected to a manifold by $6.4 \mathrm{~mm}$ diameter tycoon tubing and used for aeration. The top cover had three $60 \mathrm{~mm}$ holes, which were used as sampling ports. These holes were covered during the process with rubber stoppers. Inside the vessel, a 6.4 $\mathrm{mm}$ diameter solid stainless steel shaft was mounted on two bearings. There were five stainless steel collars on the shaft in which five bolts of $101.6 \mathrm{~mm}$ long, $6.4 \mathrm{~mm}$ diameter were mounted. The shaft was rotated by a permanent magnet variable speed $(0-250 \mathrm{rpm}), 3 / 4 \mathrm{hp}$ electric motor directly connected to a gearbox of a $30: 1$ gear reduction ratio. A speed controller controlled the speed of the motor. The air was supplied to the vessel by a $3 / 4 \mathrm{hp}$ compressor with the airflow regulated at 2.5
$\mathrm{L} / \mathrm{min}$. The supply air was passed through a $4.38 \mathrm{~L}$ Plexiglas canister that was filled with a hydroscopic silica gel which allowed the air to completely dry. The dried air was then passed through a flow meter before entering the vessel. The condensate from the saturated exhaust gas was collected in a $0.63 \mathrm{~L}$ Plexiglas water trapper. The outlet exhaust gas was then dried in another $4.38 \mathrm{~L}$ Plexiglas canister that was filled with hydroscopic Silica gel. Another flow meter was used to measure the flow rate of the outlet air before it was exhausted through tycoon tubing into the laboratory fume hood. Two rubber septums were located on the air inlet and exhaust outlet lines to provide for gas sampling. Temperature measurements were taken using nine thermocouples and data logger. The data were continuously recorded in the computer.

Preparation of contaminated soil and dry peat: A clean and dry bucket was weighed. The desired amount of soil $(10 \mathrm{~kg})$ was added to the bucket and the bucket and soil were weighed. A clean, dry glass beaker was weighed. Motor oil was added to the beaker and the desired amount of oil (200 g) and the beaker were weighed. The oil was then poured over the soil and the two were thoroughly mixed together. This resulted in a contamination level of $20 \mathrm{~g}$ oil kg$^{-1}$ soil. Another clean dry glass beaker was weighted. Peat was placed in the beaker and the desired amount of dry peat $(20 \mathrm{~g})$ and the beaker were weighed. 
Am. J. Environ. Sci., 7 (5): 477-491, 2011

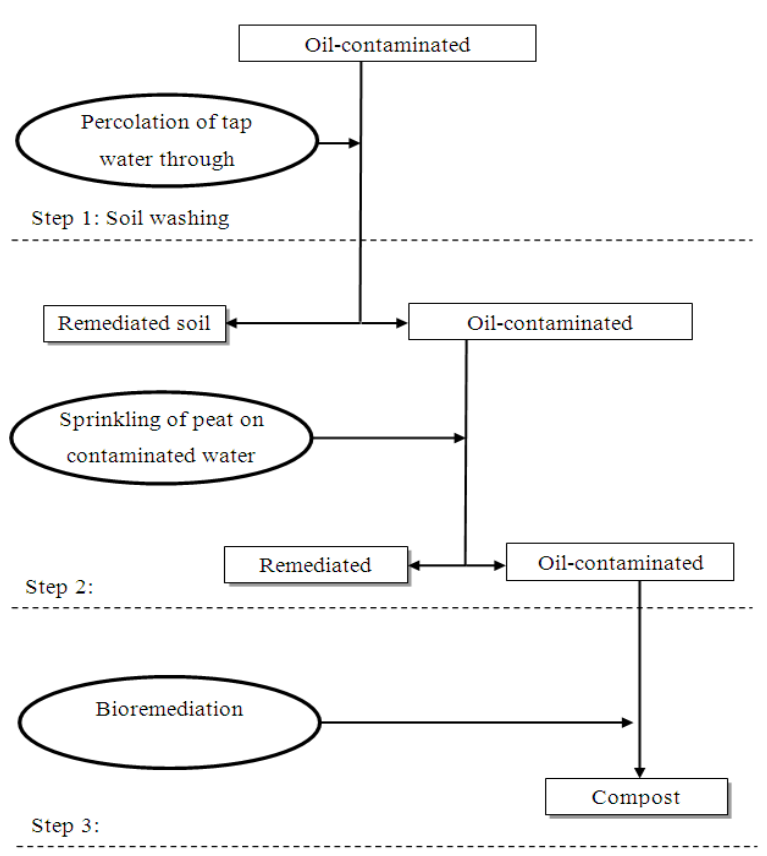

Fig. 5: Remediation procedure of oil-contaminated soil

Experimental protocol: The oil contaminated soil was remediated in three steps as shown in Fig. 5. In the first step, water was used as a solvent to separate the oil from the soil. The soil-oil mixture was poured into the soil column of the washing system and the water $(28 \mathrm{~L})$ was poured into the second column. The soil was placed in layers and each layer was compacted to achieve a homogeneous soil column. The covers were then bolted into the columns. The height of the soil was $44.58 \mathrm{~cm}$ and the height of the water was $89.17 \mathrm{~cm}$. The valves, attached to the two columns, were opened to allow water to flow from the water column to the soil column and the washing process of the oil contaminated soil began. The column containing the oil contaminated soil and water was mixed sporadically three times as recommended by Ghaly and Pyke, (2001). When the mixture (soil, water and oil) settled, three separate layers were formed as shown in Fig. 6. A soil layer at the bottom, a water layer above the soil and an oil layer above the water.

In the second step (after complete setting), the valves were turned off and the cover was removed. The peat was then applied on to the oil layer to soak up the oil. As the peat absorbed the oil (and some water), it was removed from the water and placed in a bucket. A $100 \mathrm{~mL}$ sample was taken from the water layer using specially designed skimmer. The water was then drained and filtered to remove the remaining peat. The filter paper and the collected peat were also placed in the bucket.
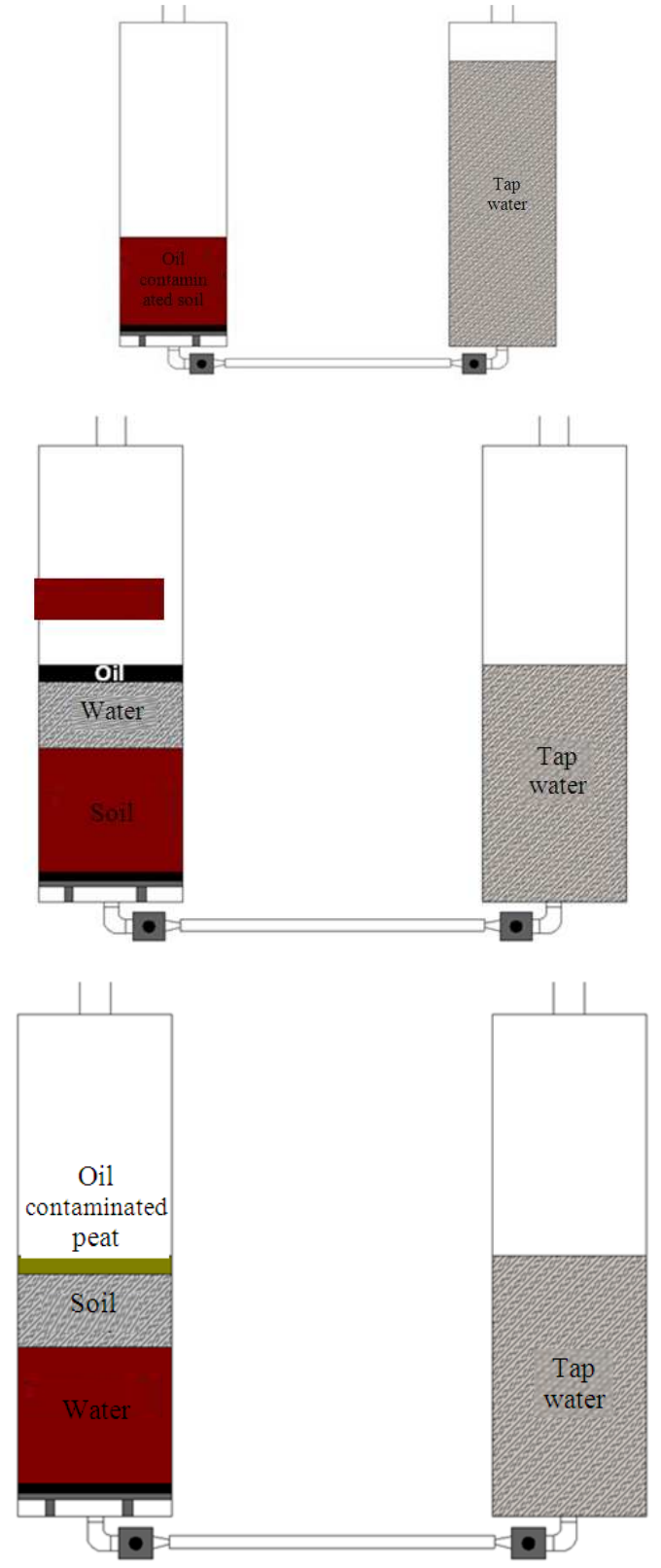

Fig. 6: Soil and water remediation steps

The top soil was scraped off the surface and sample was taken from the soil. In the third step, the contaminated peat was mixed with compost, urea and water before bioremediation. About $6.4 \mathrm{~kg}$ of peat/oil mixture were collected for several runs. About $1.3 \mathrm{~kg}$ of compost (used as a source of microbes), $0.5 \mathrm{~L}$ of phosphate buffer solution (as nutrient and $\mathrm{pH}$ control), the desired amounts of urea (as a source of nitrogen) and water were added to the large bucket containing the oil contaminated peat. The contents were mixed thoroughly 
and the moisture content and $\mathrm{C}: \mathrm{N}$ were adjusted to $70 \%$ and 30:1, respectively. The entire mixture was placed into the bioreactor. During the bioremediation process, the condensation from the saturated exhaust gas collected in the canister wasmeasured and the amount of water lost for the system was added to maintain constant moisture content.

Sampling and analysis: Samples (approximately 150 grams) were taken from the bioreactor every 5 days for moisture content, TOC, TKN, $\mathrm{NH}_{4}$, Total Carbon and total contaminated peat (diesel, water and peat mixture) samples weighing approximately $10 \mathrm{~g}$ each were placed in $100 \mathrm{~mL}$ round bottomed centrifuge test tubes. Then, $50 \mathrm{~mL}$ of a chromatographic grade solvent (hexane) was added to each of the tubes containing the contaminated meat mixture. The solvent and contaminated peat mixtures were then mixed for $10 \mathrm{~min}$ using a vortex mixer (Thermolyne, Maxi-Mix, Model no. M16715, Dubuque, Iowa). The vortex mixing allowed for sufficient liquid/solid contact and thus completes diesel recovery from the contaminated peat sample by the hexane. The mixtures were then centrifuged at $2000 \mathrm{rpm}$ for $40 \mathrm{~min}$. The supernatants (hexane/diesel/water emulsion) were carefully decanted and quantitatively transferred into $100 \mathrm{~mL}$ round bottomed centrifuge test tubes. The supernatant samples were then centrifuged at $2000 \mathrm{rpm}$ for $20 \mathrm{~min}$ to break down the emulsion into layers. The samples were then held at $-4^{\circ} \mathrm{C}$ for $12 \mathrm{~h}$. The top layer, which consisted of the hexane solvent containing diesel fuel, remained in a liquid state and was decanted. The quantitation of diesel fuel was determined using a gas chromatograph (Model no. 5890-SII, Hewlett Packard, Atlanta, Georgia). The gas chromatograph was calibrated by injecting $1.0 \mu \mathrm{L}$ of the hexane-extracted diesel fuel onto a $25 \times 0.2 \mathrm{~mm}$, $0.33 \mu \mathrm{m}$ film thickness, $5 \%$ diphenyl siloxane megabore capillary column. A split ratio of 5:1 was employed using the split mode of the injection port. The injection port was at $180^{\circ} \mathrm{C}$ and the flame inonized detector was set at $250^{\circ} \mathrm{C}$. The oven containing the column was first maintained at $40^{\circ} \mathrm{C}$ for 4 min and then increased at a rate of $10^{\circ} \mathrm{C} / \mathrm{min}$ until a final temperature of $350^{\circ} \mathrm{C}$ was reached. This final temperature was held for 5 min. The carrier gas (helium) was held at a flow arte of $1.2 \mathrm{~mL}$ min. The diesel content of the contaminated peat samples was then calculated.

The moisture content was performed on the uncontaminated peat using oven drying methods following (ASTM D3173-73) ASTM, 2001. Each sample (5 grams) was weighted using a Mettler AE 200 Balance (Model No. PM 4600, Mettler Instruments AG, Greifensee, Switzerland) and the weight was recorded to the nearest 0.0001 gram. Wet samples were oven dried at $105^{\circ} \mathrm{C}$ for $24 \mathrm{~h}$. in an air forced drying oven (Isotemp Oven, Model No. 655F, Fisher Scientific, Toronto, Ontario). Moisture content tests were also performed on the contaminated peat samples using a combination of the oven-drying procedure (ASTM D3173-73) and the modified solvent extraction procedure. The centrifuged plugs of peat obtained from the diesel measurement procedure were placed in large aluminium dishes and the moisture content of the peat was determined. The bottom layer of frozen water separated from the hexane-diesel-water mixture was weighed using a Mettler Balance (Model AE200, Mettler Instrument AG, Griefensee, Zurich) and used to calculate the initial moisture content of the contaminated peat.

Both the Total Kjeldahl Nitrogen (TKN) and ammonium nitrogen $\left(\mathrm{NH}_{4}-\mathrm{N}\right)$ were determined using a Kjeltech Auto Analyzer (Model 1030, Part No. 1000 1773, Serial No. 2000, Tecator ABHöganäs, Sweden). One gram sample of the material was diluted with 20 $\mathrm{ml}$ distilled water for $\mathrm{NH}_{4}-\mathrm{N}$ analyses. For $\mathrm{TKN}$ analyses, one gram of the material was digested with 4 $\mathrm{ml}$ of concentrated sulphuric acid $\left(\mathrm{H}_{2} \mathrm{SO}_{4}\right)$ for 25 minutes under a vacuumed ventilator. The analyte was then automatically titrated by the analyzer.

The total carbon analyses were determined at the Materials Engineering Center (MEC) of Dalhousie University using a Leco carbon analyzer (Model 516000. Leco Corporation. St. Joseph, MI, USA).

Carbon dioxide concentrations for inlet air and outlet gas were determined using a gas chromatograph (GC Model No. 5890-SII, Hewlett Packard, Atlanta, Georgia). The GC was calibrated by injecting known concentrations $(0.05,0.1,1.0,5.0,10.0 \%)$ of $1.0 \mu \mathrm{L}$ of standard calibration $\mathrm{CO}_{2}$ gas onto a $25 \times 0.2 \mathrm{~mm}, 0.33$ $\mu \mathrm{m}$ film thickness and $5 \%$ diphenyl siloxane megabore capillary column. The injection port was set at $180^{\circ} \mathrm{C}$ and the flame ionization detector was set at $250^{\circ} \mathrm{C}$. The oven containing the column was first held isothermally at $40^{\circ} \mathrm{C}$ for $4 \mathrm{~min}$ and then increased at a rate of $10^{\circ} \mathrm{C} / \mathrm{min}$ until a final temperature of $350^{\circ} \mathrm{C}$ was reached. The final temperature was held for 5 min. The carrier gas (helium) was held at a constant flow rate of $1.2 \mathrm{~mL}$ min.

\section{RESULTS}

Soil washing: In this experiment, awater to soil volume ratio of $2: 1$ by weight was used. After the water was allowed to percolate through the contaminated soil, the soil-water-oil mixture was mixed and then allowed to settle. The water took $39 \mathrm{sec}$ to pass through the soil and the entire percolation and mixing process took $176 \mathrm{sec}$. 


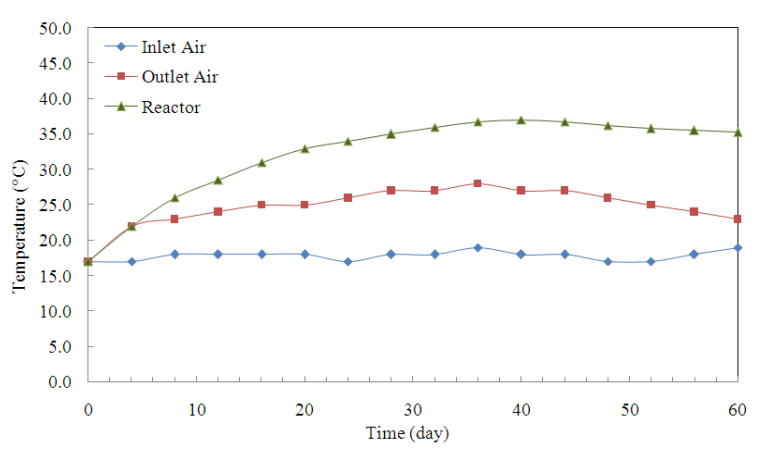

Fig. 7: Temperature profiles

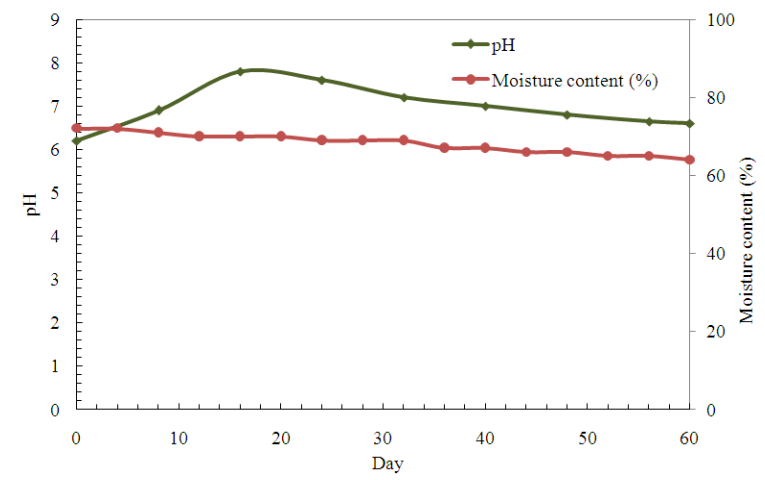

Fig. 8: $\mathrm{pH}$ and Moisture content

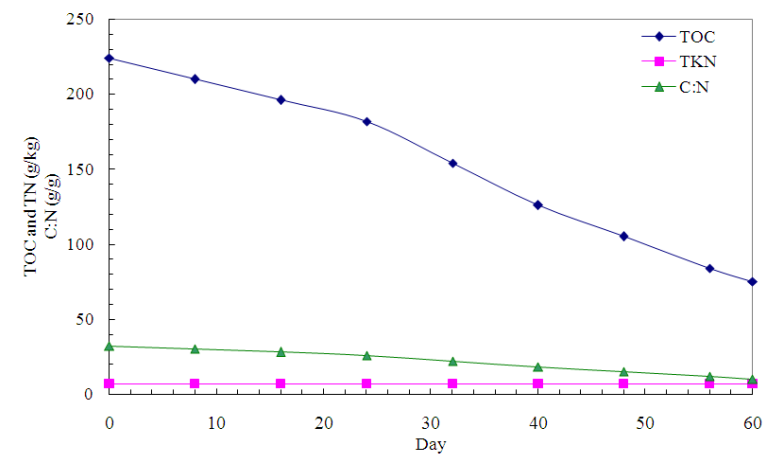

Fig. 9: Total organic carbon, total kjeldahl nitrogen and $\mathrm{C}: \mathrm{N}$ ratio

The time required for complete separation of the mixture into 3 layers was $350 \mathrm{sec}$ after which the water was clear. The depth of the soil layer increased slightly from $44.60-45.25 \mathrm{~cm}$. The water layer above the soil was $15.42 \mathrm{~cm}$ and the oil layer was $0.71 \mathrm{~cm}$.

Absorption of oil by peat: The initial moisture content of the peat was $7.1 \%$. The final total moisture and diesel content of the peat was $92.44 \%$.
The amount of oil added to the soil was $200 \mathrm{~g}$. The total amount of oil and water absorbed by peat was $225.16 \mathrm{~g}(25.16+200 \mathrm{~g}$ oil). The peat absorbed about 12.6 times its weight liquid.

Peat bioremediation: Temperature: The profiles of the average bioreactor temperature, the inlet air temperature and the outlet gas temperature are presented in Fig. 7. The maximum temperature reached in the bioreactor was $37^{\circ} \mathrm{C}$ indicating that the hemophilic microorganisms were the dominant group in the bioremediation process. The maximum temperature $\left(37^{\circ} \mathrm{C}\right.$ was reached on day 31 and remained constant for 20 days before declining on the 51 day.

Moisture content: The initial moisture content was $70 \%$ which started to decline with time reaching $62 \%$ by day 60 as shown in Fig. 8. This indicated that the loss of water in the exhaust gas was higher than that produced by microbial respiration and decomposition of organic materials.

pH: The initial $\mathrm{pH}$ was 6.2 which increased initially reaching 7.8 by day 16 and gradually declined reaching 6.6 by the end of experiment as shown in Fig. 8 .

Total organic carbon: The changes in Total Organic Carbon (TOC) during the bioremediation process are shown in Fig. 9. The total organic carbon decreased with time, initially at a slow rate till day 24 and then decreased at a faster rate. An initial reduction of $18 \%$ in total carbon (from 224-182 $\mathrm{g} \mathrm{kg}^{-1} \mathrm{db}$ ) was observed after the first 24 days of bioremediation. A total reduction of $66.5 \%$ in organic carbon (from 224-75 g $\mathrm{kg}^{-1} \mathrm{db}$ ) was observed after 60 days of bioremediation.

Total Kjeldahl Nitrogen: The changes in Total Kjeldahl Nitrogen (TKN) followed a similar pattern as TOC are shown in Fig. 9. The initial TKN was $7 \mathrm{~g} \mathrm{~kg}^{-1}$ material $(\mathrm{db})$ which decreased to $5 \mathrm{~g} \mathrm{~kg}^{-1}$ material $(\mathrm{db})$ by the end of the experiment resulting in a total reduction of $28 \%$ in TKN.

C:N ratio: The $\mathrm{C}: \mathrm{N}$ ratio was affected by the reductions in TOC and TKN. The $\mathrm{C}: \mathrm{N}$ ratio declined with time from the initial value of 30:1 reaching 12:1 by the end of the experiment as shown in Fig. 9. This indicated that the reduction in TOC was much faster than the reduction in TKN.

$\mathrm{CO}_{2}$ evolution: The breakdown of organic matter resulted in the production of $\mathrm{CO}_{2}$. The $\mathrm{CO}_{2}$ increased from $0.05 \%$ (in the inlet air) to $3.4 \%$ (in the exhaust 484 
Am. J. Environ. Sci., 7 (5): 477-491, 2011

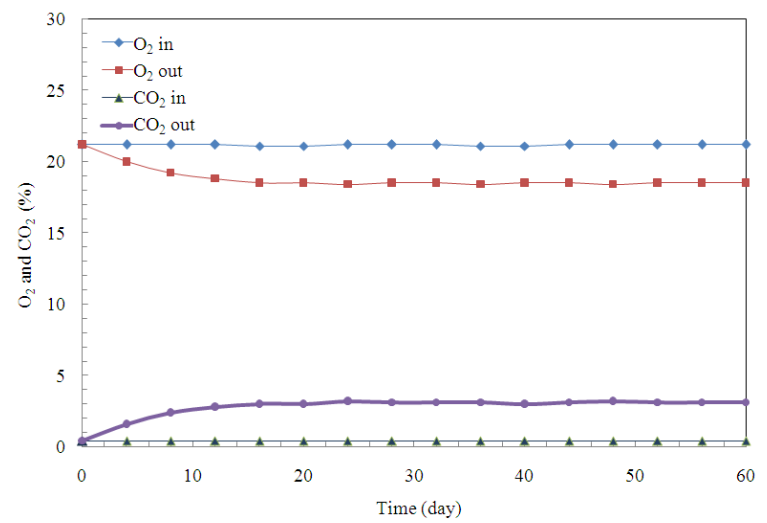

Fig. 10: Carbon dioxides and oxygen content in the inlet air and outlet exhaust

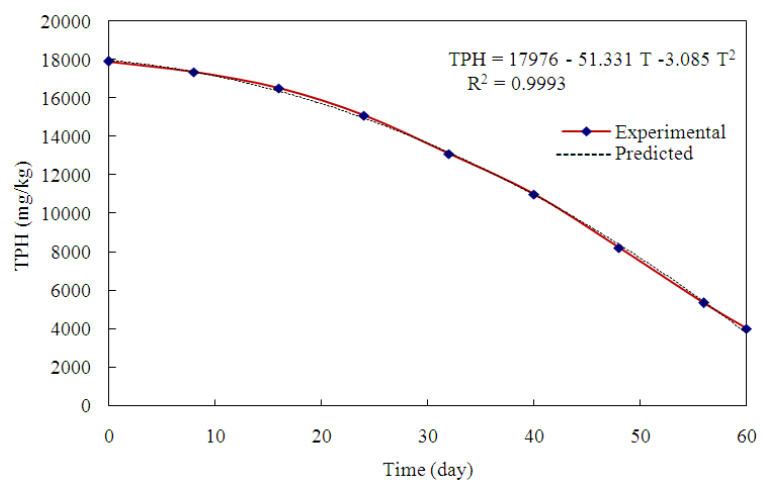

Fig. 11: TPH content

This was also reflected in the $\mathrm{O}_{2}$ content which decreased from $20.9 \%$ (in the inlet air) to $17.4 \%$ (in the exhaust gas) as shown in Fig. 10.

Total Petroleum Hydrocarbon: The initial concentration of Total Petroleum Hydrocarbon (TPH) was $17900 \mathrm{mg} \mathrm{kg}^{-1}$ which declined with time reaching $4000 \mathrm{mg} \mathrm{kg}^{-1}$ by the end of the experiment as shown in Fig. 11. The total reduction of TPH in peat at the end of the experiment was $77.65 \%$.

\section{DISCUSSION}

Oil removal from soil and water: The mass balance performed on water indicated that the he soil voids occupied about $31 \%$ of the soil volume. The analysis of water and soil sample showed no oil residues in both media which indicated that $100 \%$ of the oil was removed from the soil by the water washing process and from the water by peat. The peat absorbed about 12.6 times of its weight liquid $(88.83 \%$ oil and $11.17 \%$ water).
Viraraghaven and Mathavan (1988) reported a 83\% removal efficiency of a standard mineral oil and 70\% removal efficiency of a crude oil from wastewater using peat. Smith et al. (1976) reported 83-97\% oil removal capacities from wastewater using activated/modified peat $\left(\mathrm{H}_{2} \mathrm{SO}_{4}\right.$-treated peat $)$ compared to $89-97 \%$ removal efficiencies for a synthetic absorbent. Asplund et al. (1978) reported 98\% oil removal efficiency using 0.05 $\mathrm{m}$ thick bed for commercial sorbing peat. Ghaly and Pyke (2001) reported $99.99 \%$ oil removal efficiency from oil contaminated water using commercial peat. Martin et al. (1991) reported on the potentiability of peat as an oil absorbing material and suggested several possible interactions between the peat and contaminants including: (a) cation exchange with $\mathrm{H}+$ found in the$\mathrm{COOH}$ phenolic hydroxyl and heterocyclic groups, (b) interaction of metallic cations to form chelate complexes and (c) formation of anion-cation bonds. However, these interactions are reliant on the characteristics of the contaminant and the peat.

Peat bioremediation: Temperature: The average inlet air temperature was $18 \pm 1^{\circ} \mathrm{C}$. The temperature of bioreactor gradually increased from $18-37^{\circ} \mathrm{C}$ at the 31 day and remained constant for 20 days before declining on the 51 day. The average bioreactor temperature increased with time due to microbial decomposition of the petroleum hydrocarbons and the peat organic matter. Microbes utilize organic matter under aerobic conditions for energy (respiration) and growth (synthesis) as described by the following equations (Alkoaik and Ghaly, 2006b) Eq. 1 and 2:

Energy

$\mathrm{C}_{\mathrm{x}} \mathrm{H}_{\mathrm{y}} \mathrm{O}_{\mathrm{z}}+\mathrm{O}_{2}$ Microbes $\mathrm{CO}_{2}+\mathrm{H}_{2} \mathrm{O}+$ Heat

Synthesis

$\mathrm{C}_{\mathrm{x}} \mathrm{H}_{\mathrm{y}} \mathrm{O}_{\mathrm{z}}+\mathrm{NH}_{4}$ Microbes more microbes

A small part of the energy generated in Eq. 1 is used by the microbes for synthesizing substrates into structural cell parts (protoplasm, cell wall.) while the rest appears as heat that raised the temperature of the material in the bioreactor (sensible heat) and caused the evaporation of the moisture (latent heat). Some of the heat was also lost from the material with the exhaust gas and through the bioreactor body. The results exhibited the effects of metabolic activity of mesophilic groups of microbes.

Atagana (2008) reported a maximum temperature of $58^{\circ} \mathrm{C}$ (due to high initial microbial load) in the second month of bioremediation of hydrocarbon contaminated soil inoculated with sewage sludge and 
wood chips which remained relatively stable until the end of the third month when started to decrease reaching $30^{\circ} \mathrm{C}$ after 19 months. Hua et al. (2008) observed a maximum temperature of $65^{\circ} \mathrm{C}$ on day 7 while composting polycyclic aromatic hydrocarbons in sewage sludge which then declined to $35^{\circ} \mathrm{C}$ after 15 day and reached ambient temperature after 30 days. Ghaly et al. (2007) reported maximum steady temperatures of 32 and $40^{\circ} \mathrm{C}$ after $60 \mathrm{~h}$ for continuous and intermittent mixing during the bioremediation of toluene contaminated soil. They stated that continuous mixing caused more heat losses with exhaust gas compared to intermittent mixing. Alkoaik and Ghaly (2006b) reported a maximum temperature of $40^{\circ} \mathrm{C}$ while composting greenhouse tomato plant residues with dairy manure. Cookson (1995) reported successful degradation of petroleum products contaminated soil during composting under ambient temperature conditions of $20-30^{\circ} \mathrm{C}$.

Moisture content: The moisture content declined from $70-62 \%$ due to the loss of water with the exhaust gas. The reported optimum range of moisture content for composting is $25-80 \%$ on a wet basis (Golueke, 1977; Tiquia et al., 1996; Epstein, 1997). However, the ideal moisture content is in the range of 50-70 with $60 \%$ being the optimal for in-vessel composting (AntizarLadislao et al., 2007). According to Walker et al. (1999), an intense decrease of moisture content will reduce the metabolic rate and affects the effectiveness of the bioremediation process while high moisture content can reduce the oxygen transfer.

Hua et al. (2008) reported a steadily decreasing trend of moisture content from an initial value of $62.5 \%$ to a final value of $30.2 \%$ after 60 days during the composting of sewage sludge mixed with rapeseed marc. Guardia et al. (2010) observed a decrease in the moisture content of composted food waste with wood chips the mixture from $63.4-50.5 \%$ after 37 days of composting. Ghaly et al. (2007) reported a small reduction in the moisture content (from 60-59.47\%) during the bioremediation of toluene contaminated soil. Ghaly and Mahmoud (2006) reported a reduction in the moisture content from $60.7-59 \%$ during composting of green house tomato plant residues with dairy manure. Ma et al. (2001) reported $82.69 \%$ removal of hydrocarbons at a moisture content within the range of $55-60 \%$ during in-vessel bioremediation of petroleum solid waste. Antizar-Ladislao et al. (2006) reported removal efficiencies of large PAHs of 52.3, 24.9 and $0 \%$ at moisture contents of 60,80 and $40 \%$, respectively during in-vessel bioremediation of an aged coal tar contaminated soil at $38^{\circ} \mathrm{C}$.
pH: The $\mathrm{pH}$ of the compost mixture rose during the first 2 weeks from 6.2-7.8 and then declined reaching 6.6 by the end of the experiments. During the early stages of the biodegradation process, decomposition of hydrocarbons and release of $\mathrm{NH} 4+$ may be the reason for the rise in $\mathrm{pH}$. The gradual increase in microbial activity and degradation of organic matter and hydrocarbons resulted in the release of acidic intermediates and $\mathrm{CO}_{2}$ production that probably lowered the $\mathrm{pH}$ of the mixture (Golueke 1977; Alexander, 1999).

Mihial et al. (2006) reported an initial $\mathrm{pH}$ of 7.49 which first increased to 8.03 and then decline to 7.05 at the end of experiment during bioremediation of petroleum-contaminated soil. Tang et al. (2007) observed an increase in the $\mathrm{pH}$ from 8.0-9.2 in the first week which then decreased to 8.6 after 21 days during composting cattle manure with rice straw.

Total organic carbon: The TOC decreased at slower rate $\left(1.75 \mathrm{~g} \mathrm{~kg}^{-1} . \mathrm{d}\right)$ during the first 3 weeks and then decreased at much faster rate $\left(2.97 \mathrm{~g} \mathrm{~kg}^{-1}\right.$.d) during the rest of the experiment. Acclimatization of microorganisms to the new environment and the production of essential enzymes may be the reason for less reduction in the early stage of bioremediation. A total reduction of $66.8 \%$ in TOC was achieved in 60 days. The average reduction rate of total carbon observed in this experiment was 2.48 $\mathrm{g} \mathrm{kg}^{-1} \cdot \mathrm{d}(1.1 \% /$ day $)$.

Martin, (1991) reported a total carbon reduction of $24 \%$ while composting yard trimming waste for 45 days. Marin et al. (2006) achieved a much slower rate of TOC reduction $\left(0.75 \mathrm{~g} \mathrm{~kg}^{-1} . \mathrm{d}\right)$ during the bioremediation of oil refinery sludge mixed with wood savings and pig slurry after 12 weeks of composting. Ayotamuno et al. (2010) achieved very slow rate of TOC reduction $\left(0.053 \mathrm{~g} \mathrm{~kg}^{-1} . \mathrm{d}\right)$ during the bioremediation of petroleum sludge mixed with poultry manure and saw dust after 42 days of composting.

TKN: The TKN decreased from $7 \mathrm{~g} \mathrm{~kg}^{-1}-5 \mathrm{~g} \mathrm{~kg}^{-1}$ (28\%) in 60 days. The reductions in TKN were slower than the reductions in the total carbon due to low initial concentration of total nitrogen and the high concentration of bioavailable carbon. Similar results were reported by Rao et al. (1995). Ghaly and Mahmoud (2006) reported a TKN reduction of $55.6 \%$ after 60 days during in-vessel bioremediation process of hydrocarbons contaminated soil. Spinelli et al. (2005) reported a slower reduction of $25 \%$ in TKN (from 10 $\mathrm{mg} \quad \mathrm{kg}^{-1}-\mathrm{O} \quad 7.5 \quad \mathrm{mg} \quad \mathrm{kg}^{-1}$ ) during in-vessel 
bioremediation of diesel contaminated soil mixed with food industry sludge after 170 days of bioremediation. Ghaly and Mahmoud (2006) reported 61\% reduction in TKN while composting greenhouse tomato plant residues with dairy manure.

C:N ratio: A $\mathrm{C}$ : $\mathrm{N}$ ratio of $30: 1$ is recommended for effective bioremediation of organic compounds (Alkoaik and Ghaly, 2006a). In a biological decomposition system, the $\mathrm{C}$ : $\mathrm{N}$ ratio would typically decrease because: (a) the organic carbon is oxidized to $\mathrm{CO}_{2}$ faster than ammonium is oxidized to $\mathrm{NO}_{3}$-and (b) nitrogen can remain relatively stable if the balance between mineralization of organic nitrogen to $\mathrm{NH} 4$ and the immobilization of $\mathrm{NH} 4$ to organic nitrogen (microbial growth) is maintained during the process (Wang et al., 2003).

The C: $\mathrm{N}$ ratio reduction in present study was $60 \%$, which corresponds to values reported by Lopez-Real and Baptista (1996), Michel et al., 1995; 1996) and Alkoaik and Ghaly (2006a). Beaudin et al. (1999) observed a $68 \%(49: 1-17: 1)$ reduction of $\mathrm{C}: \mathrm{N}$ ratio and reported that the apparent degradation of soilderived mineral oil and grease increased substantially as the C: $\mathrm{N}$ ratio was reduced. Similar results have been obtained in landfarming where a $\mathrm{C}$ : $\mathrm{N}$ ratio of 18 (lowest ratio tested) resulted in maximum oil decomposition (Rasiah et al., 1991).

CO 2 evolution: $\mathrm{CO}_{2}$ evolution is used to judge the microbial activity in bioremediation process. Generally, more metabolic activity of microorganisms evolutes more $\mathrm{CO}_{2}$. The decomposition of organic materials (TPH and peat) caused a substantial increase (6700\%) in the $\mathrm{CO}_{2}$ in the exhaust gas (from $0.05-3.4 \%$ ) and a $16.75 \%$ decrease in the $\mathrm{O}_{2}$ (from 20.9-17.4\%). The increases in the $\mathrm{CO}_{2}$ in the exhaust gas confirm the higher microbial activity of mesophilic bacteria.

Atagana (2008) reported 58\% (from 1500-2000 $\mu \mathrm{g} / \mathrm{dwt} /$ day) increase of $\mathrm{CO}_{2}$ during the bioremediation of hydrocarbon contaminated soil inoculated with sewage sludge and wood chips for 19 months. They observed relatively stable $\mathrm{CO}_{2}$ after the thirteen month and fluctuating between 2300 and $2000 \mu \mathrm{g} / \mathrm{dwt} / \mathrm{day}$ for the remainder of bioremediation period. Beaudin et al. (1999) reported that about $6.8 \mathrm{moL}$ of $\mathrm{CO}_{2} \mathrm{~kg}^{-1}$ of initial dry compost was produced during 30 days of weathered hydrocarbon contaminated soil composting when the plateau temperature was in the range of 23$50^{\circ} \mathrm{C}$, but declined sharply to $3.2 \mathrm{moL}$ of $\mathrm{CO}_{2} \mathrm{~kg}^{-1}$ of initial dry compost when the plateau was kept at $60^{\circ} \mathrm{C}$.

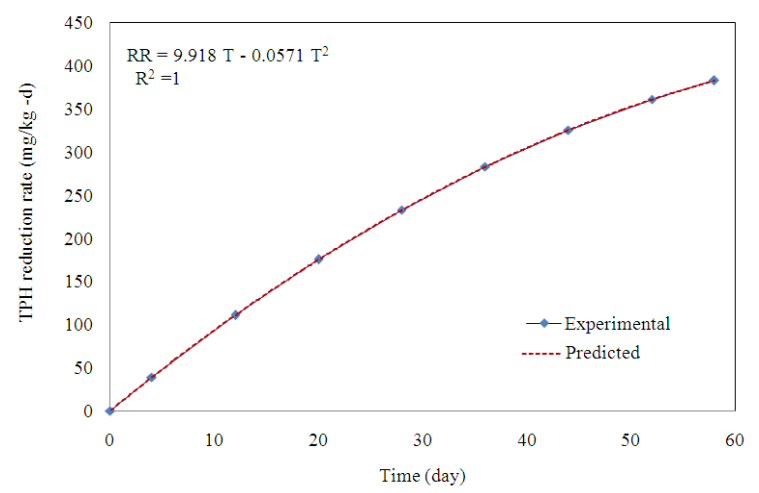

Fig. 12: TPH reduction rate

Spinelli et al. (2005) reported $10 \mathrm{gm} \mathrm{kg}^{-1}$ of $\mathrm{CO}_{2}$ evolution during the in-vessel bioremediation of diesel contaminated soil mixed with food industry sludge after 170 days of bioremediation. Ghaly et al. (2007) reported a decline in $\mathrm{O}_{2}$ from 20.94-15.96\% and an increase in $\mathrm{CO}_{2}$ from $0.03-1.69 \%$ during the bioremediation of toluene contaminated soil.

Total petroleum hydrocarbon: The TPH content of the peat was reduced from $17900-400 \mathrm{mg} \mathrm{kg}^{-1}$. The data was fitted in to the following polynomial Eq. 3:

$\mathrm{TPH}=17976-51.331 \mathrm{~T}-3.085 \mathrm{~T} 2$

Where:

$\mathrm{TPH}=$ Total petroleum hydrocarbons $\left(\mathrm{mg} \mathrm{kg}^{-1}\right)$

$\mathrm{T} \quad=$ Time (day)

The model provided good a fit $\left(\mathrm{R}_{2}=0.999\right)$ to the experimental data as shown in Fig. 11. Based on the above model, it is expected that a complete degradation of the hydrocarbons will be achieved in 68.5 days.

The results sown in Fig. 11 indicated that the microbial population appeared to have acclimatized to the hydrocarbons as seen by the immediate reduction of hydrocarbons content of the peat. As the microbial population increased in number the reduction rate increased with time as shown in Fig. 12. The initial reduction rate during the first $8 \mathrm{~h}$ was $38.7 \mathrm{mg} \mathrm{kg}^{-1}-\mathrm{d}$ which increased to $383 \mathrm{mg} \mathrm{kg}-1$-d by the end of the experiment. The change in the hydrocarbon reduction rate can be described by the following Eq. 4:

$\mathrm{RR}=9.918 \mathrm{~T}-0.0571 \mathrm{~T} 2$

Where:

$\mathrm{RR}=$ Total petroleum hydrocarbons reduction rate $(\mathrm{mg}$ $\mathrm{kg}^{-1}$-day) 
$\mathrm{T}=$ Time (day)

About $77.65 \%$ reductions in TPH were achieved in 60 days giving an average bioremediation rate of approximately $231.67 \mathrm{mg} \mathrm{kg}^{-1}$ soil-day. This is higherthan $220 \mathrm{mg} \mathrm{kg}^{-1}$-day reported by Hinchee and Arthur (1991), $212 \mathrm{mg} \mathrm{kg}^{-1}$ day reported by Alkoaik and Ghaly (2006a), $155 \mathrm{mg} \mathrm{kg}^{-1}$-day by Mihial et al. (2006) and the $102 \mathrm{mg} \mathrm{kg}^{-1}$ day by Critchley (2000).

\section{CONCLUSION}

The remediation of petroleum hydrocarbon contaminated soil included three processes: (a) an effective soil washing process for the removal of the hydrocarbons from the contaminated soil, (b) an efficient water decontamination process using peat moss as an oil absorbent and (c) an effective bioremediation process for converting the oil in peat moss into carbon dioxide and water. The results showed that water is an effective solvent for the removal of oil from contaminated soil and peat moss is an effective absorbent of oil from the contaminated water. It can absorb 12.6 times its weight liquid (water/oil). The bioremediation process was effective in degrading the oil into harmless carbon dioxide and water products. About $77.65 \%$ of the THC was removed within 60 days of bioremediation and total degradation of oil could be achieved in 68.5 days. The microbial population was soon acclimatized to the hydrocarbon as was evident from the immediate rise in temperature and degradation of hydrocarbons. The rate of hydrocarbons degradation increased from $38.7 \mathrm{mg} \mathrm{kg}^{-1}$-d (in first week) to $383 \mathrm{mg}$ $\mathrm{kg}^{-1}$-day by the end of the experiment. The moisture content decreased from $70-62 \%$ by the end of the experiment. The $\mathrm{C}$ : $\mathrm{N}$ ratio decreased from 30:1-12:1 indicating the degradation of organic $\mathrm{C}$ in the petroleum hydrocarbon and the peat. Urea was very effective source of nitrogen in initiating and maintaining intense microbial respiration activity.

\section{ACKNOWLEDGEMENTS}

This researcher was funded by the National Science and Engineering Research Council (NSERC) of Canada.

\section{REFERENCES}

Alexander, M., 1999. Biodegradation and Bioremediation. 2nd Edn., Academic Press, San Diego, ISBN: 0120498618, pp: 453.

Alkoaik, F. and A.E. Ghaly, 2006a. Thermobioremediation of soil contaminated with used motor oil. Ene. Sour. Part A: Recov. Utilization Environ. Effe., 28: 487-500. DOI: 10.1080/009083190925392
Alkoaik, F. and A.E. Ghaly, 2006b. Influence of dairy manure addition on the biological and thermal kinetics of composting of greenhouse tomato plant residues, Waste Manage., 26: 902-913. DOI: 10.1016/j.wasman.2005.11.023

Alonso-Alvarez, C., C. Perez and A. Velando, 2007. Effects of acute exposure to heavy fuel oil from the Prestige spill on a seabird. Aquatic Toxicol., 84: 103-110. DOI:10.1016/j.aquatox.2007.06.004

Arnold, W.L. and W.L. Anderson, 2002. Biotechnology Deskbook. 1st Edn., Environmental Law Institute, Washington DC, USA., ISBN: 1585760293, pp: 250 .

Antizar-Ladislao, B., J. Lopez-Real and A.J. Beck, 2006. Degradation of Polycyclic Aromatic Hydrocarbons (PAHs) in an aged coal tar contaminated soil under in-vessel composting conditions. Environ. Pollu., 141: 459-468. DOI: 10.1016/j.envpol.2005.08.066

Antizar-Ladislao, B., A.J. Beck, K. Spanova, J. LopezReal and N.J. Russell, 2007. The influence of different temperature programmes on the bioremediation of polycyclic aromatic hydrocarbons (PAHs) in a coal-tar contaminated soil by in-vessel composting. J. Hazardous Mater., 144: 340-347. DOI: 10.1016/j.jhazmat.2006.10.031

Asplund, D., E. Ekman and R. Thun, 1978. Removal of hydrocarbon using peat. Proceedings, 5th International Peat Congress, Poznam, Poland, pp: 359-371.

Astera, M., 2010. The Ideal Soil: A Handbook for the New Agriculture. 1st Edn., SoilMinerals.com, Washington, ISBN-10: 0984487603, pp: 138.

Atagana, H.I., 2008. Compost bioremediation of hydrocarbon-contaminated soil inoculated with organic manure. African J. Biotechnol., 7: 15161525 .

Atlas, R.M., 1995. Bioremediation of petroleum pollutants. Int. Biodeterioration Biodegradation, 35: 317-327. DOI: 10.1016/0964-8305(95)00030-9

Ayotamuno, J.M., R.B. Kogbara, E.A. Agele and O.S. Agoro, 2010. Composting and phytoremediation treatment of petroleum sludge. Soil Sediment Contamination, 19: 686-695.

Baars, B.J., 2002. The wreckage of the oil tanker 'Erika'-human health risk assessment of beach cleaning, sunbathing and swimming. Toxicol. Lett., 128: 55-68. PMID: 11869817

Beilen, J.B.V., Z. Li, W.A. Duetz, T.H.M. Smits and B. Witholt, 2003. Diversity of alkane hydroxylase systems in the environment. Oil Gas Sci. Technol.Rev. IFP, 58: 427-440. DOI: 10.2516/ogst:2003026 
Filler, D.M., I. Snape, D.L. Barnes, 2008. Bioremediation of Petroleum Hydrocarbons in Cold Regions. Cambridge University Press, Cambridge, ISBN-10: 0521869706, pp: 273.

Barrington, S.F. and R.G. Moreno, 1995. Swine manure nitrogen conservation in storage using sphagnum moss. J. Environ. Qual., 24: 603-607.

Beaudin, N., R.F. Caron, R. Legros, J. Ramsay and B. Ramsay, 1999. Identification of the key factors affecting composting of a weathered hydrocarboncontaminated soil. Biodegradation, 10: 127-133. DOI: $10.1023 / \mathrm{A}: 1008365832031$

Capotorti, G., P. Digianvincenzo, P. Cesti, A. Bernardi and G. Guglielmetti, 2004. Pyrene and benzo (a) pyrene metabolism by an Aspergillus terreus strain isolated from a polycylic aromatic hydrocarbons polluted soil. Biodegradation, 15: 79-85. DOI: 10.1023/B:BIOD.0000015612.10481.e6

Chen, K.F., C.M. Kao, C.W. Chen, R.Y. Surampalli and M.S. Lee, 2010. Control of petroleumhydrocarbon contaminated groundwater by intrinsic and enhanced bioremediation. J. Environ. Sci., 22: 864-871. DOI: 10.1016/S10010742(09)60190-X

Chu, W. and K.H. Chan, 2003. The mechanism of the surfactant-aided soil washing system for hydrophobic and partial hydrophobic organics. Sci. Total Environ., 307: 83-92. DOI: 10.1016/S00489697(02)00461-8

Cookson, J.T., 1995. Bioremediation Engineering: Design and Application. 1st Edn., McGraw-Hill, New York, ISBN: 10: 0070126143, pp: 524.

Critchley, J.G., 2000. Composting of soils contaminated with heavy petroleum hydrocarbons. University of Ottawa.

Metman, L.V., K. Kompoliti and L. Verhagen, 2010. Encyclopedia of Movement Disorders. 1st Edn., Academic Press, Amsterdam, ISBN-10: 0123741017 , pp: 1518.

Cullina, W., 2008. Native Ferns, Moss and Grasses. 1st Edn., Houghton Mifflin Harcourt, Boston, ISBN10: 0618531181, pp: 256.

Dermatas, D. and X. Meng, 2003. Utilization of fly ash for stabilization/solidification of heavy metal contaminated soils. Eng. Geol., 70: 377-394. DOI: 10.1016/S0013-7952(03)00105-4

Epstein, E., 1997. The Science of Composting. 1st Edn., Technomic Publishing Company, Lancaster, ISBN: 1566764785 , pp: 487.

Fingas, M.F., 1995. A literature review of the physics and predictive modelling of oil spill evaporation. J. Hazardous Mater., 42: 157-175. DOI: 10.1016/0304-3894(95)00013-K
Ghaly, R.A., J.B. Pyke, A.E. Ghaly and V.I. Ugursal, 1999. Physical and thermochemical properties of uncontaminated and diesel-contaminated peat. Ene. Sour., 21: 433-451. DOI: 10.1080/00908319950014740

Ghaly, A.E. and J.B. Pyke, 2001. In-vessel bioremediation of oil-contaminated peat. Ene. Sour., 23: 305-325. DOI: 10.1080/009083101300110869

Ghaly, A.E. and N.S. Mahmoud, 2006. Optimum conditions for measuring dehydrogenase activity of Aspergillus niger using TTC. Am. J. Biochem. Biotechnol., 2: 186-194. DOI: 10.3844/ajbbsp.2006.186.194

Ghaly, A.E., D.G. Rushton and K. Martinell, 2007. Effect of mixing on the biological degradation of toluene under aerobic conditions. Am. J. Environ. Sci., 3: 247-258. DOI: 10.3844/ajessp.2007.247.258

Golueke, C.G., 1977. Biological Reclamation of Solid Wastes. 1st Edn., Rodale Press, Emmaus, PA., ISBN-10: 0878571582, pp: 249.

Guardia, A.D., P. Mallard, C. Teglia, A. Marin and C.L. Pape et al., 2010. Comparison of five organic wastes regarding their behavior during composting: Part 1, biodegradability, stabilization kinetics and temperature rise. Waste Manage., 30: 402-414. DOI: 10.1016/j.wasman.2009.10.019

Hinchee, R.E. and M. Arthur, 1991. Bench scale studies of the soil aeration process for bioremediation of petroleum hydrocarbons. Applied Biochem. Biotechnol., 28-29: 901-906. PMID: 1929391

Hua, L., W. Wu, Y. Liu, Y. Chen and M.B. McBride, 2008. Effect of composting on polycyclic aromatic hydrocarbons removal in sewage sludge. Water Air Soil Poll., 193: 259-267. DOI: 10.1007/s11270008-9687-y

Kubota, K., D. Koma, Y. Matsumiya, S.Y. Chung and M. Kubo, 2008. Phylogenetic analysis of longchain hydrocarbon-degrading bacteria and evaluation of their hydrocarbon-degradation by the 2,6-DCPIP assay. Biodegradation, 19: 749-757. DOI: $10.1007 / \mathrm{s} 10532-008-9179-1$

Lee, R.F. and D.S. Page, 1997. Petroleum hydrocarbons and their effects in subtidal regions after major oil spills. Marine Poll. Bull., 34: 928-940. DOI: 10.1016/S0025-326X(97)00078-7

Lopez-Real, J. and M. Baptista, 1996. A preliminary comparative study of three manure composting systems and their influence on process parameters and methane emissions. Compost Sci. Utilization, 4: 71-82. 
Maier, R.M., I.L. Pepper and C.P. Gerba, 2000. Environmental Microbiology. 1st Edn., Academic Press, London, ISBN: 0124975704, pp: 585.

Marin, J.A., J.L. Moreno, T. Hernandez and C. Garcia, 2006. Bioremediation by composting of heavy oil refinery sludge in semiarid conditions. Biodegradation, 17: 251-261. DOI: 10.1007/s10532-005-5020-2

Martin, A.M., 1991. Composting Process. Bioconversion of Waste Materials to Industrial Products. 2nd Edn., Blackie Academic and Professional, London, ISBN: 0751404233, pp: 556.

Martin, J., T. Langer, R. Boteva, A. Schramel, A.L. Horwich et al., 1991. Chaperonin-mediated protein folding at the surface of groEL through a 'molten globule'-like intermediate. Nature 352: 36-42. DOI:10.1038/352036a0

Michel, F.C., C.A. Reddy and L.J. Forney, 1995. Microbial degradation and humification of the lawn care pesticide 2,4-dichlorophenoxyacetic acid during the composting of yard trimmings. Applied Environ. Microbiol., 61: 2566-2566.

Michel, F.C., L.J. Forney, A.J.F. Huang, S. Drew and M. Czuprenski et al., 1996. Effects of turning frequency, leaves to grass ratio and windrow vs. pile configuration of the composting of yard trimmings. Compost Sci. Utilization, 4: 26-43.

Mihial, D.J., T. Viraraghavan and Y.C. Jin, 2006. Bioremediation of petroleum-contaminated soil using composting. Practice Periodical Hazardous, Toxic Radioactive Waste Manage., 10: 108-115.

Mihopoulos, P.G., M.T. Suidan, G.D. Sayles and S. Kaskassian, 2002. Numerical modeling of oxygen exclusion experiments of anaerobic bioventing. J. Contaminant Hydrol., 58: 209-220. DOI: 10.1016/S0169-7722(02)00037-2

Mitsch, W.J. and J.G. Gosselink, 2007. Wetlands. 4th Edn., John Wiley and Sons, Hoboken, ISBN: 0471699675, pp: 582.

Ma, Y., J.Y. Zhang, M.H. Wong and W.Z. Wu, 2001. Optimization of control parameters for petroleum waste composting. J. Environ. Sci., 13: 385-390. PMID: 11723920

Pavel, L.V. and M. Gavrilescu, 2008. Overview of ex situ decontamination techniques for soil cleanup. Environ. Eng. Manage. J., 7: 815-834.

Prince1, R.C., R.R. Lessard and J.R. Clark, 2003. Bioremediation of marine oil spills. Oil Gas Sci. Technol., 58: 463-468. DOI: 10.2516/ogst:2003029

Rao, N., H.E. Grethlein and C.A. Reddy, 1995. Effect of $\mathrm{C} / \mathrm{N}$ ratio and moisture content on the composting of poplar wood. Biotechnol. Lett., 17: 889-892. DOI: 10.1007/BF00129024
Rasiah, V., R.P. Voroney and R.G. Kachanoski, 1991. Effect of $\mathrm{N}$ amendment on $\mathrm{C}$ mineralization of an oily waste. Water Air Soil Pollution, 59: 249-259. DOI: 10.1007/BF00211834

Riser-Roberts, E., 1992. Bioremediation of Petroleum Contaminated Sites. 1st Edn., C.K. Smoley, Chelsea, ISBN: 0873718321, pp: 496.

Rodriguez-Trigo, G., J.P. Zock and I.I. Montes, 2007. Health effects of exposure to oil spills. Archivos de Bronconeumología, 43: 628-635. DOI: 10.1016/S1579-2129(07)60141-4

Roland, U., D. Buchenhorst, F. Holzer and F.D. Kopinke, 2008. Engineering aspects of radio-wave heating for soil remediation and compatibility with biodegradation. Environ. Sci. Technol., 42: 12321237. DOI: 10.1021/es0713680

Rushton, D.G., A.E. Ghaly and K. Martinell, 2007. Assessment of canadian regulations and remediation methods for diesel oil contaminated soils. Am. J. Applied Sci., 4: 465-478. DOI: 10.3844/ajassp.2007.465.478

Scott, T., 1996. Concise Encyclopedia Biology. 1st Edn., Walter de Gruyter, Berlin, ISBN: 3110106612, pp: 1287.

Sherwood, L.J. and R.G. Qualls, 2001. Stability of phosphorus within a wetland soil following ferric chloride treatment to control eutrophication. Environ. Sci, Technol., 35: 4126-4131.

Smith, E.F., B. Mark and H.B. Marj, Jr., 1976. The characterization of phosphoric acid-treated peat as a cation exchanger. J. Environ. Sci. Health Environ. Sci. Eng. Part A: Environ. Sci. Eng., 11: 179-189. DOI: 10.1080/10934527609385764

Spinelli, L.F., F. Schnaid, P.A. Selbach, F.M. Bento and J.R. Oliveira, 2005. Enhancing bioremediation of diesel oil and gasoline in soil amended with an agroindustry sludge.. J. Air Waste Manag. Assoc., 55: 421-429. PMID: 15887885

Suthersan, S.S., 1997. Remediation Engineering: Design Concepts. 1st Edn., CRC-Lewis Publishers, Boca Raton, FL, ISBN: 1566701376, pp: 362.

Tang, J.C., A. Shibata, Q. Zhou and A. Katayama, 2007. Effect of temperature on reaction rate and microbial community in composting of cattle manure with rice straw. J. Bioscience Bioeng., 104: 321-328. DOI: 10.1263/jbb.104.321

Tiquia, S.M., N.F.Y. Tam and I.J. Hodgkiss, 1996. Microbial activities during composting of spent pig-manure sawdust litter at different moisture contents. Bioresource Technol., 55: 201-206. DOI: 10.1016/0960-8524(95)00195-6 
Toyoda, M. and M. Inagaki, 2000. Heavy oil sorption using exfoliated graphite: New application of exfoliated graphite to protect heavy oil pollution. Carbon, 38: 199-210. DOI: 10.1016/S00086223(99)00174-8

Trevors, J.T., 2010. One gram of soil: a microbial biochemical gene library. Antoine Van Leeuwenhoek, 97: 99-106. DOI: 10.1007/s10482009-9397-5

Viraraghaven, T. and G.N. Mathavan, 1988. Treatment of oil-in-water emulsions using peat. Oil Chemical Poll., 4: 261-280. DOI: 10.1016/S02698579(88)80002-9

Wang, J.Y., O. Stabnikova, S.T.L. Tay, V. Ivanov and J.H. Tay, 2003. Intensive bioconversion of sewage sludge and food waste by Bacillus thermoamylovorans. World J. Microbiol. Biotechnol., $\quad$ 19: $\quad 427-432 . \quad$ DOI: 10.1023/A:1023933212654
Waites, M.J., 2001. Industrial Microbiology: An Introduction. 1st Edn. John Wiley and Sons, Malden, ISBN: 0632053070, pp:288.

Walker, L.P., T.D. Nock, J.M. Gossett and J.S. VanderGheynst, 1999. The role of periodic agitation and water addition in managing moisture limitations during high-solids aerobic decomposition. Process Biochem., 34: 601-612. DOI: $10.1016 / S 0032-9592(98) 00122-8$

Wentzel, A., T.E. Ellingsen, H.K. Kotlar, S.B. Zotchev and M. Throne-Holst, 2007. Bacterial metabolism of long-chain n-alkanes. Applied Microbiol. Biotechnol., 76: 1209-1221. DOI: 10.1007/s00253007-1119-1 